\title{
Are coalminers, with low "risk factors" for ischaemic heart disease at greater risk of developing progressive massive fibrosis?
}

\author{
A L COCHRANE, ${ }^{1}$ F MOORE, ${ }^{1 *}$ AND C B MONCRIEFF ${ }^{2}$ \\ From MRC Epidemiology Unit, ${ }^{1}$ Cardiff CF2 3AS, and MRC Pneumoconiosis Unit, ${ }^{2}$ Llandough Hospital, \\ Penarth CF6 IXW, UK
}

ABSTRACT Coalminers with "A" shadows (the first stage of progressive massive fibrosis (PMF)) have a similar standardised mortality ratio (SMR) to those without PMF, and those with A shadows have a much higher specific mortality from pneumoconiosis. It is therefore argued that either A shadows confer immunity against some other disease(s) or that those developing A shadows are selected on the basis of increased life expectancy. These two hypotheses were investigated and as the selection hypothesis appeared promising further studies were made to discover which specific cause of death might be associated with this selection. This, surprisingly, appeared to be ischaemic heart disease.

Progressive massive fibrosis (PMF) is recognised as by far the more serious type of coalworkers' pneumoconiosis, but, apart from the increased risk of developing PMF associated with category of simple pneumoconiosis, ${ }^{12}$ little is known about its aetiology except that it is apparently not associated with smoking habit or further dust exposure. ${ }^{1}$ It is agreed that the prevalence of PMF is low among British coalminers still in the pits but high among those attending the pneumoconiosis panels. Those who leave mining with categories 2 and 3 simple pneumoconiosis are still at risk of developing PMF, at the rate of about $2 \%$ a year, ${ }^{1}$ as this is independent of further dust exposure.' PMF remains a serious problem.

\section{Materials}

The materials used here consist of the results of two 20-year follow-up studies in the Rhondda Fach ${ }^{3}$ (A L Cochrane, F Moore, unpublished observations) and one each in Leigh, Lancs, ${ }^{4}$ and Staveley, Derbyshire. $^{5}$

\section{Results}

The argument starts from the observation based on

*Supported in part by a grant from the National Coal Board.

Received 19 October 1981

Accepted 27 November 1981 the 1950-8 Rhondda Fach follow-up that the casefatality rate for men with A shadows was similar to that of the non-miners ${ }^{6}$ (fig 1) (table 1). It should be remembered that the non-miners in the Rhondda Fach had a significantly lower mortality than miners and ex-miners without PMF. ${ }^{3}$ The 20 -year followup in the Rhondda Fach $^{3}$ showed a slight change in that the SMR of men with A shadows is now the same as category 0 (table 2 ) and similar to the values of Jacobsen's 14-year follow-up. ${ }^{7}$ Finally Miller's 22-year follow-up ${ }^{8}$ shows that the SMR of men with $A$ shadows is still rising. One gets the impression of some factor, associated with early A shadows lowering mortality, being gradually overwhelmed by the progression of $\mathrm{A}$ shadows to $\mathrm{B}$ and $\mathrm{C}$. This finding is remarkable as those with $\mathrm{A}$ shadows have a considerably raised specific mortality from pneumoconiosis (table 3 ), ${ }^{3}$ and if one examines the mortality of the two groups (table 4), excluding deaths from coalworkers' pneumoconiosis, the difference is significant $(p<0.03)$. One explanation is that $\mathrm{A}$ shadows confer immunity from some other disease(s), but this is considered to be unlikely. Another explanation is that among men at risk of developing PMF, those with increased life expectancy are preferentially attacked-"selection" or "protection."

We thought we could decide between these two theories by comparing the mortality rates of miners and ex-miners without PMF in mining areas with different prevalences of PMF. According to the 


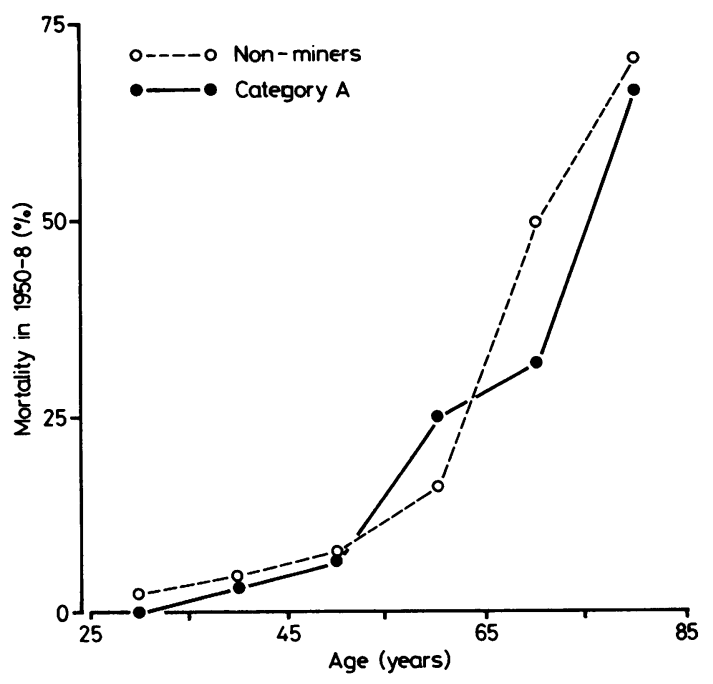

Fig 1 Male mortality in the Rhondda Fach.

Table 1 Mortality of non-miners and of miners and ex-miners with category $A$ in the Rhondda Fach 1950-8

\begin{tabular}{|c|c|c|c|c|}
\hline \multirow[t]{2}{*}{ Age } & \multicolumn{2}{|c|}{ Non-miners } & \multicolumn{2}{|c|}{ Category $A$} \\
\hline & No & No (\%) of deaths & No & No $(\%)$ of deaths \\
\hline $\begin{array}{l}25-34 \\
35-44 \\
45-54 \\
55-64 \\
65-74 \\
75-84 \\
\geqslant 85 \\
\text { Total }\end{array}$ & $\begin{array}{r}737 \\
447 \\
223 \\
148 \\
64 \\
27 \\
5 \\
1651\end{array}$ & $\begin{array}{r}14(1.9) \\
19(4.3) \\
17(7.6) \\
23(15.5) \\
32(50.0) \\
19(70.4) \\
3(60.0) \\
127\end{array}$ & $\begin{array}{r}39 \\
87 \\
101 \\
112 \\
67 \\
12 \\
1 \\
419\end{array}$ & $\begin{array}{rr}- & (0.0) \\
3 & (3.4) \\
7 & (6.9) \\
28 & (25.0) \\
21 & 31 \cdot 3) \\
8 & (66.7) \\
1(100.0) & (100.0) \\
68 & \end{array}$ \\
\hline
\end{tabular}

Table 2 SMRs of men in the Rhondda Fach 1950-70

\begin{tabular}{lcc}
\hline Group & \multicolumn{2}{l}{ SMRs (age 25-74) } \\
\cline { 2 - 3 } & $\begin{array}{l}\text { Observed } \\
\text { deaths }\end{array}$ & SMR \\
\hline Non-miners & 357 & 98.7 \\
Miners and ex-miners & & \\
Category 0 & 1242 & 120.3 \\
Category 1, 2, and 3 & 711 & 117.2 \\
Category A and C & 189 & $120 \cdot 1$ \\
Category B and C & 467 & 195.1 \\
\hline
\end{tabular}

Table 3 Specific mortality for pneumoconiosis for Rhondda Fach miners and ex-miners 1950-70

\begin{tabular}{|c|c|c|c|c|c|c|}
\hline \multirow{2}{*}{$\begin{array}{l}\text { Age } \\
\text { groups }\end{array}$} & \multicolumn{3}{|c|}{ Categories $0,1,2$, and 3} & \multicolumn{3}{|c|}{ Category $A$} \\
\hline & No & Dead & $\%$ & No & Dead & $\%$ \\
\hline $\begin{array}{l}25-44 \\
45-64 \\
65-74\end{array}$ & $\begin{array}{r}2187 \\
1960 \\
522\end{array}$ & $\begin{array}{r}12 \\
20 \\
9\end{array}$ & $\begin{array}{l}0.5 \\
1.0 \\
1.7\end{array}$ & $\begin{array}{r}136 \\
176 \\
59\end{array}$ & $\begin{array}{r}3 \\
23 \\
7\end{array}$ & $\begin{array}{r}2.2 \\
13.1 \\
11.9\end{array}$ \\
\hline
\end{tabular}

Table 4 Mortality excluding deaths from pneumoconiosis for Rhondda Fach miners and ex-miners 1950-70

\begin{tabular}{|c|c|c|c|c|c|c|}
\hline \multirow{2}{*}{$\begin{array}{l}\text { Age } \\
\text { groups }\end{array}$} & \multicolumn{3}{|c|}{ Categories $0,1,2$, and 3} & \multicolumn{3}{|c|}{ Category $A$} \\
\hline & No & Dead & $\%$ & No & Dead & $\%$ \\
\hline $\begin{array}{l}25-44 \\
45-64 \\
65-74\end{array}$ & $\begin{array}{r}2187 \\
1960 \\
522\end{array}$ & $\begin{array}{r}280 \\
1156 \\
476\end{array}$ & $\begin{array}{l}12 \cdot 8 \\
59 \cdot 0 \\
91 \cdot 2\end{array}$ & $\begin{array}{r}136 \\
176 \\
59\end{array}$ & $\begin{array}{l}21 \\
88 \\
47\end{array}$ & $\begin{array}{l}15.4 \\
50.0 \\
79.7\end{array}$ \\
\hline
\end{tabular}

selection theory the mortality of those without PMF should be higher in the high prevalence areas, as those with, potentially, greater life expectancy will have been selected out into the PMF group. According to the protection theory there should be no such difference.

We have done this using our four 20-year follow-up studies in three mining areas. Table 5 and fig 2 show that the mortality of those without PMF in the low prevalence areas is definitely lower than in high prevalence areas. The difference between Staveley mortality and the Rhondda Fach 1950-70 mortality is significant $(p<0.04)$. It is worth while adding that this is not a chance finding associated with the well-known differences in death rates in regions of the country. The death rates for the "non-dusty" male death rates in the three areas are actually in the reverse order to that of miners and ex-miners.

It is unfortunate that there are so few long-term follow-up studies of miners and ex-miners in mining areas, but we consider the results favour the selection hypothesis. It should also be noted that the hypothesis gains in explanatory power by solving the problem of the differences between Staveley and the Rhondda Fach as regards mortality (fig 3 ). In the Rhondda Fach the mortality rate of those miners and ex-miners without PMF is significantly higher than that of the non-miners, ${ }^{3}$ while in Staveley the mortality of the non-miners is similar to that of the miners and ex-miners without PMF. ${ }^{s}$

One of us (ALC) had previously suggested that the difference between Staveley and the Rhondda

Table 5 Mortality of men aged 55-64 in four surveys in three areas compared with prevalence of PMF. (All 20-year follow-ups standardised for age)

\begin{tabular}{lcl}
\hline Area & $\begin{array}{l}\text { Percentage prevalence } \\
\text { of } P M F\end{array}$ & $\begin{array}{l}\text { Mortality miners and } \\
\text { ex-miners. Categories } \\
0,1,2 \text {, and 3 }\end{array}$ \\
\hline $\begin{array}{l}\text { Rhondda Fach } \\
\text { (1958-78) }\end{array}$ & 30.9 & 74.7 \\
$\begin{array}{l}\text { Rhondda Fach } \\
(1950-70)\end{array}$ & 23.1 & 76.7 \\
$\begin{array}{l}\text { Leigh } \\
(1954-74)\end{array}$ & 4.7 & 69.4 \\
$\begin{array}{l}\text { Staveley } \\
(1957-77)\end{array}$ & 0.0 & 67.1 \\
\hline
\end{tabular}




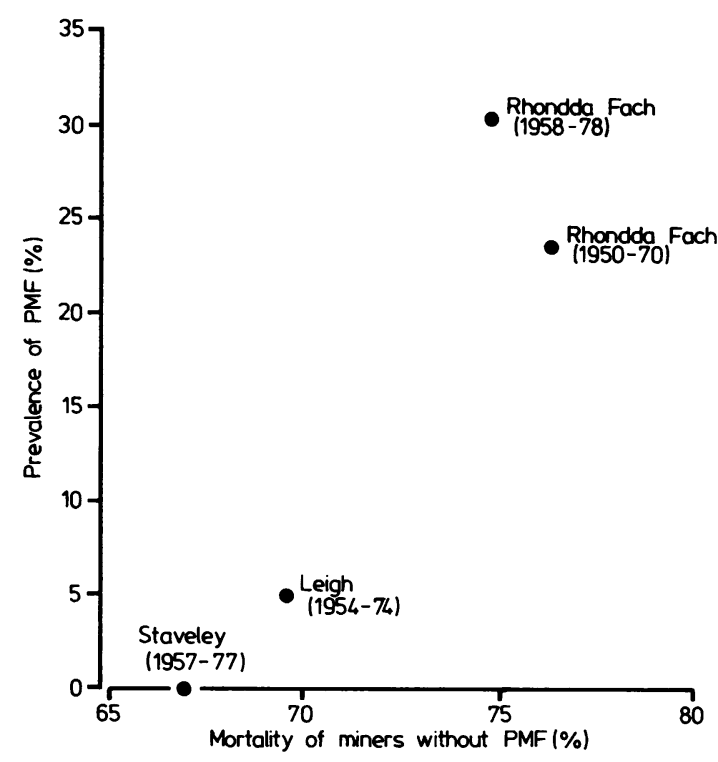

Fig 2 Miners' mortality in four surveys in three mining areas.
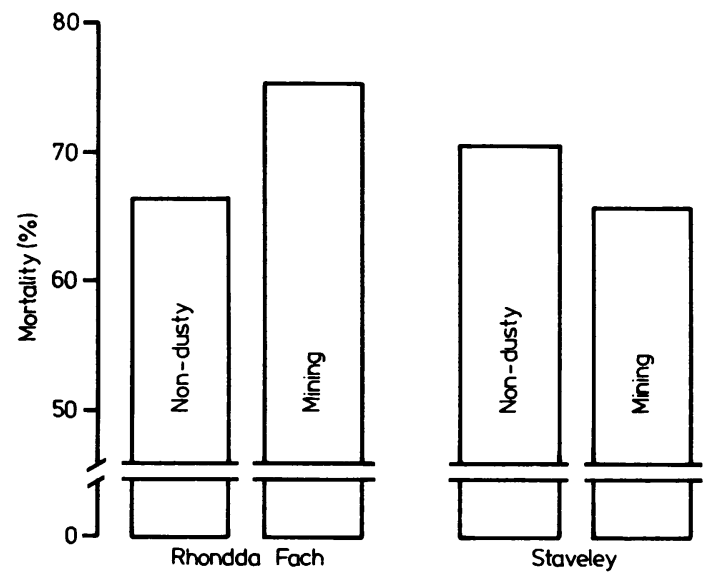

Fig 3 Mortality of "non-dusty" men and miners aged 55-64 without PMF. (Twenty-year follow-up.)
Fach could be explained by selective migration. ${ }^{9}$ We are at present analysing the migration pattern in the Rhondda Fach between 1950 and 1970 and have found the migration theory no longer tenable.

The next step was to attempt to discover which specific cause(s) of death accounted for these differences in total mortality. We have in the past 30 years learnt to be suspicious about causes of death as certified. We have seen fashions change. So we have omitted the earliest Rhondda 1950-70 follow-up from this section. We were looking for a cause of death that puts the three areas in the correct ranking order, according to prevalence of PMF, and where the differences in specific mortality were sufficiently large to account for the differences in total mortality (table 6).

To our surprise ischaemic heart disease (ICD/8 B28) was the only specific cause to give us exactly what we wanted and enable us to complete our hypothesis. Unfortunately many factors are associated with ischaemic heart disease death rates and few have been investigated in relation to the attack rate of PMF. All we can say is that "smoking habit" is not the factor linking PMF to ischaemic heart disease.

At this stage it is necessary to consider an alternative though closely related hypothesis-"preselection." It is generally accepted that those who survive working at the coal face long enough to reach categories 2 and 3 are different from those who leave the coal face early with categories 0 and 1. No one so far has pin-pointed the difference, but those who later reach categories 2 and 3 are generally thought of as being tougher, harder working, fitter, or more interested in money. They are, however, certainly selected in some way, and possibly the selection process for the attack of PMF could take place at this level.

We have attempted to test this preselection theory in the following way. We argued that if this theory held, those with categories 2 and 3 at Staveley (where there is little PMF) should have lower total and ischaemic heart disease mortality than those

Table 6 Specific mortality of miners and ex-miners aged 55-64 in three surveys. (Number of deaths in parentheses)

\begin{tabular}{|c|c|c|c|c|c|c|c|}
\hline \multirow[t]{2}{*}{ Area } & \multicolumn{7}{|c|}{ Causes of death (ICD/8) } \\
\hline & No & $\begin{array}{l}\text { Cancer } \\
\text { B19 }\end{array}$ & $\begin{array}{l}I H D \\
B 28\end{array}$ & $\begin{array}{l}C V A \\
B 30\end{array}$ & $\begin{array}{l}\text { Other circulatory } \\
\text { B26, 27, } 29\end{array}$ & $\begin{array}{l}\text { Respiratory } \\
\text { B31, 32, } 33\end{array}$ & Other \\
\hline $\begin{array}{l}\text { Rhondda Fach } \\
(1958-78) \\
\text { Leigh } \\
(1954-74) \\
\text { Staveley } \\
(1957-77)\end{array}$ & $\begin{array}{r}65 \\
80 \\
149\end{array}$ & $\begin{array}{l}15 \cdot 4 \\
(10) \\
17 \cdot 5 \\
(14) \\
14 \cdot 8 \\
(22)\end{array}$ & $\begin{array}{l}29.2 \\
(19) \\
22 \cdot 5 \\
(18) \\
16 \cdot 1 \\
(24)\end{array}$ & $\begin{array}{r}6.2 \\
(4) \\
10.0 \\
(8) \\
6.7 \\
(10)\end{array}$ & $\begin{array}{c}6 \cdot 2 \\
(4) \\
2 \cdot 5 \\
(2) \\
6 \cdot 7 \\
(10)\end{array}$ & $\begin{array}{c}10 \cdot 8 \\
(7) \\
8.8 \\
(7) \\
12.1 \\
(18)\end{array}$ & $\begin{array}{c}9 \cdot 2 \\
(6) \\
6 \cdot 3 \\
(5) \\
9 \cdot 4 \\
(14)\end{array}$ \\
\hline
\end{tabular}

IHD = Ischaemic heart disease.

CVA $=$ Cerebrovascular accident. 
with categories 0 and 1 (table 7). Though the numbers are small, there is really little support for the preselection theory, although it cannot be entirely ruled out.

Table 7 Total mortality and ischaemic heart disease mortality in Staveley 1957-77

\begin{tabular}{|c|c|c|c|c|c|}
\hline & \multirow[t]{2}{*}{ No } & \multicolumn{2}{|c|}{ Total mortality } & \multicolumn{2}{|c|}{$\begin{array}{l}\text { Ischaemic hear } \\
\text { mortality }\end{array}$} \\
\hline & & No & $(\%)$ & No & $(\%)$ \\
\hline $\begin{array}{l}\text { Categories } \\
0 \text { and } 1 \\
2 \text { and } 3 \\
\text { Total }\end{array}$ & $\begin{array}{r}123 \\
26 \\
149\end{array}$ & $\begin{array}{l}82 \\
16 \\
98\end{array}$ & $\begin{array}{l}(66 \cdot 7) \\
(61 \cdot 5) \\
65 \cdot 8)\end{array}$ & $\begin{array}{r}19 \\
5 \\
24\end{array}$ & $\begin{array}{l}(15.4) \\
(19.2) \\
(16 \cdot 1)\end{array}$ \\
\hline
\end{tabular}

Work is continuing in Cardiff in two directions: (1) an analysis of the factors associated with the ischaemic heart disease death rate in Rhondda Fach miners and ex-miners, and non-miners; and (2) a study, with the help of the pneumoconiosis medical panel, of factors related to the attack rate of PMF.

We think the selection part of the hypothesis is well founded, and this certainly suggests it may be unwise to "pool" miners from areas with different prevalences of PMF when studying mortality. Our distrust of the accuracy of death certification makes us more sceptical of the ischaemic heart disease idea.

\section{References}

' Cochrane AL. The attack rate of progressive massive fibrosis. $\mathrm{Br}$ $J$ Ind Med 1962;19:52-62.

${ }^{2}$ McLintock JS, Rae S, Jacobsen M. The attack rate of progressive massive fibrosis in British coal mines. In: Walton WH, ed. Inhaled particles III. Old Woking, Surrey: Unwin, 1971:93352.

${ }^{3}$ Cochrane AL, Haley TJL, Moore F, Hole D. The mortality of men in the Rhondda Fach 1950-70. Br J Ind Med 1979;36: 15-22.

${ }^{4}$ Cochrane AL, Moore F. Preliminary results of a 20-year follow-up of a random sample of an industrial town. $\mathrm{Br}$ Med $\mathrm{J}$ 1978;i:411-2.

${ }^{5}$ Cochrane AL, Moore F. A 20-year follow-up of men aged 5564 , including coalminers and foundry workers in Staveley, Derbyshire. Br J Ind Med 1980;37:226-9.

- Cochrane AL, Moore F, Thomas J. The prognostic value of radiological classification in cases of progressive massive fibrosis, Tubercle 1961;42:64-71.

7 Jacobsen M. Dust exposure, lung diseases and coalminers mortality. Edinburgh: University of Edinburgh, 1976. (Thesis for $\mathrm{Ph}$ D.)

${ }^{8}$ Miller BG, Jacobsen M, Steele RC. Coalminers' mortality in relation to radiological category, lung function and exposure to airborne dust. Edinburgh: Institute of Occupational Medicine, 1981. (IOM Report No TM/81/10 (Eur P87) CEC Contract 7246 16/8/001 UDC 312.2: 622.872.)

${ }^{9}$ Cochrane AL, Higgins ITT, Thomas J. Pulmonary ventilatory functions of coalminers in various areas in relation to the $x$-ray category of pneumoconiosis. Br J Prev Soc Med 1961;15: $1-11$. 